\title{
Comparative study of the antioxidant and reactive oxygen species scavenging properties in the extracts of the fruits of Terminalia chebula, Terminalia belerica and Emblica officinalis
}

\author{
Bibhabasu Hazra† ${ }^{\dagger}$, Rhitajit Sarkar†, Santanu Biswas and Nripendranath Mandal*
}

\begin{abstract}
Background: Cellular damage caused by reactive oxygen species (ROS) has been implicated in several diseases, and hence natural antioxidants have significant importance in human health. The present study was carried out to evaluate the in vitro antioxidant and reactive oxygen species scavenging activities of Terminalia chebula, Terminalia belerica and Emblica officinalis fruit extracts.

Methods: The $70 \%$ methanol extracts were studied for in vitro total antioxidant activity along with phenolic and flavonoid contents and reducing power. Scavenging ability of the extracts for radicals like DPPH, hydroxyl, superoxide, nitric oxide, hydrogen peroxide, peroxynitrite, singlet oxygen, hypochlorous acid were also performed to determine the potential of the extracts.

Results: The ability of the extracts of the fruits in exhibiting their antioxative properties follow the order T. chebula $>E$. officinalis $>$ T. belerica. The same order is followed in their flavonoid content, whereas in case of phenolic content it becomes $E$. officinalis $>T$. belerica $>T$. chebula. In the studies of free radicals' scavenging, where the activities of the plant extracts were inversely proportional to their $I C_{50}$ values, T. chebula and $E$. officinalis were found to be taking leading role with the orders of $T$. chebula $>$ E. officinalis $>T$. belerica for superoxide and nitric oxide, and $E$. officinalis $>T$. belerica $>T$. chebula for DPPH and peroxynitrite radicals. Miscellaneous results were observed in the scavenging of other radicals by the plant extracts, viz., T. chebula $>$ T. belerica $>$ E. officinalis for hydroxyl, T. belerica $>T$. chebula $>E$. officinalis for singlet oxygen and T. belerica $>$ E. officinalis $>T$. chebula for hypochlorous acid. In a whole, the studied fruit extracts showed quite good efficacy in their antioxidant and radical scavenging abilities, compared to the standards.

Conclusions: The evidences as can be concluded from the study of the $70 \%$ methanol extract of the fruits of Terminalia chebula, Terminalia belerica and Emblica officinalis, imposes the fact that they might be useful as potent sources of natural antioxidant.
\end{abstract}

\section{Background}

Oxidative stress plays an important role in the pathogenesis of various diseases such as atherosclerosis, alcoholic liver cirrhosis and cancer etc. Oxidative stress is initiated by reactive oxygen species (ROS), such as superoxide anion $\left(\mathrm{O}^{-2}\right)$, perhydroxy radical (HOO-) and hydroxyl radical (HO.). These radicals are formed by a one electron

\footnotetext{
* Correspondence: mandaln@rediffmail.com

1 Division of Molecular Medicine, Bose Institute, P-1/12 CIT Scheme VIIM,

Kolkata-700054, India

+ Contributed equally

Full list of author information is available at the end of the article
}

reduction process of molecular oxygen $\left(\mathrm{O}_{2}\right)$. ROS can easily initiate the lipid peroxidation of the membrane lipids, causing damage of the cell membrane of phospholipids, lipoprotein by propagating a chain reaction cycle $[1,2]$. Thus, antioxidants defense systems have coevolved with aerobic metabolism to counteract oxidative damage from ROS. Most living species have efficient defense systems to prevent themselves against oxidative stress induced by ROS [3]. Recent investigations have shown that the antioxidant properties of plants could be correlated with oxidative stress defense and different human 
diseases and aging process etc [4]. In this respect flavonoids and other polyphenolic compounds have received the greatest attention.

The fruits of Terminalia chebula Retz, Terminalia belerica Roxb, and Emblica officinalis Gaertn are widely used in the Indian traditional system of medicine [5]. The half ripe fruit of $T$. belerica and the pericarp of $T$. chebula fruit were reported to be purgative [5]. The fruit of $T$. chebula was traditionally used to cure asthma, urinary disorders, heart disease and it has cardiotonic activity $[6,7]$. In Ayurveda, the fruit of E. officinalis is used as a cardiotonic, cerebral and intestinal tonic [8], and it is also reported to have anticancer properties $[9,8]$. The fruit of E. officinalis is a rich source of vitamin C, a well-known antioxidant [10]. The crude extract of E. officinalis was reported to counteract the hepatotoxic and renotoxic effects of metals [11] due to antioxidant properties.

This present study is aimed to assess the antioxidant capacity of the $70 \%$ methanol extracts of T. chebula, T. belerica and $E$. officinalis fruits, through their measurement of activities in scavenging of different free radicals including hydroxyl, superoxide, nitric oxide, hydrogen peroxide, peroxynitrite, singlet oxygen, hypochlorous acid, phenol, flavonoid and ascorbic acid content and total antioxidant activity with ABTS and DPPH.

\section{Methods}

\section{Chemicals}

2,2'-azinobis-(3-ethylbenzothiazoline-6-sulfonic acid) (ABTS) was obtained from Roche diagnostics, Mannheim, Germany. 6-hydroxy-2,5,7,8-tetramethylchroman-2-carboxylic acid (Trolox) was obtained from Fluka, Buchs, Switzerland. Potassium persulfate $\left(\mathrm{K}_{2} \mathrm{~S}_{2} \mathrm{O}_{8}\right)$, 2deoxy-2-ribose, mannitol, sodium nitroprusside (SNP), lipoic acid 5,5'-dithiobis-2-nitrobenzoic acid (DTNB), 1chloro-2,4-dinitrobenzene (CDNB), glutathione reduced and quercetin were obtained from Sisco Research Laboratories Pvt. Ltd, Mumbai, India. Folin-ciocalteu reagent, xylenol orange and $N, N$-dimethyl-4-nitrosoaniline were obtained from Merck, Mumbai, India. Gallic acid, 1,1Diphenyl-2-Picrylhydrazyl (DPPH) and curcumin were obtained from MP Biomedicals, France. Catalase was obtained from HiMedia Laboratories Pvt. Ltd, Mumbai, India. Evans blue was purchased from BDH, England. Diethylene-triamine-pentaacetic acid (DTPA) was obtained from Spectrochem Pvt. Ltd, Mumbai, India.
Thiobarbituric acid (TBA) was obtained from Loba Chemie, Mumbai, India.

\section{Plant material}

The fruits of T. chebula, T. belerica and E. officinalis were collected from Bankura district of West Bengal, India. The plant was identified by the Central Research Institute (Ayurveda), Kolkata, India, where specimens of each plant were deposited (Table 1).

\section{Animals}

Male Swiss albino mice $(20 \pm 2 \mathrm{~g})$ were purchased from Chittaranjan National Cancer Institute (CNCI), Kolkata, India and were maintained under a constant 12-h dark/ light cycle at an environmental temperature of $22 \pm 2^{\circ} \mathrm{C}$. The animals were fed with normal laboratory pellet diet and water ad libitum. The institutional animal ethics committee approved all experimental procedure.

\section{Extraction}

The powder (100 g) of the individual normal air-dried fruits of T. chebula, T. belerica and E. officinalis were stirred using a magnetic stirrer with a 7:3 mixture of methanol: water $(500 \mathrm{ml})$ for 15 hours; the mixture was then centrifuged at $2850 \times g$ and the supernatant decanted. The process was repeated by adding the solvent with the precipitated pellet. The supernatants were collected, concentrated in a rotary evaporator [250-200 mbar at $37^{\circ} \mathrm{C}$ ] and lyophilized. The yields for the plants materials were $5.6 \mathrm{~g}, 3.7 \mathrm{~g}$ and $4.2 \mathrm{~g}$ for T. chebula, T. belerica and $E$. officinalis, respectively. The dried extracts were stored at $-20^{\circ} \mathrm{C}$ until use.

\section{In vitro Antioxidant assay Total antioxidant activity}

Antioxidant capacity was measured based on the scavenging of ABTS.+ radical cation by the sample in comparison to trolox standard [12]. ABTS solution was mixed with potassium persulfate and incubated for 12-16 $\mathrm{h}$ in dark to generate ABTS ${ }^{+}$radical cation. Then $10 \mu \mathrm{l}$ sample solution was mixed with $1 \mathrm{ml} \mathrm{ABTS}{ }^{+}$solution and the absorbance was measured at $\lambda=734 \mathrm{~nm}$. All experiments were repeated six times. The percentage inhibition of absorbance was calculated and plotted as a function of concentration of standard and sample to determine the trolox equivalent antioxidant concentration (TEAC). To

Table 1: Voucher specimen number of three plants

\begin{tabular}{ccc}
\hline SI. No. & Plant & Specimen No. \\
\hline 1. & Terminalia chebula & CRHS 113/08 \\
2. & Terminalia belerica & CRHS 114/08 \\
3. & Emblica officinalis $115 / 08$ \\
\hline
\end{tabular}


calculate the TEAC, the gradient of the plot for the sample was divided by the gradient of the plot for trolox.

\section{$D P P H$ radical scavenging assay}

The complementary study for the antioxidant capacity of the fruit extract was confirmed by the DPPH scavenging assay according to Mahakunakorn et al. [13], with slight modification. Different concentrations $(0-100 \mu \mathrm{g} / \mathrm{ml})$ of the extracts and the standard trolox were mixed with equal volume of ethanol. Then $50 \mu \mathrm{l}$ of DPPH solution (1 $\mathrm{mM}$ ) was pipetted into the previous mixture and stirred thoroughly. The resulting solution was kept standing for 2 minutes before the optical density (OD) was measured at $\lambda=517 \mathrm{~nm}$. The measurement was repeated with six sets. The percentage radical scavenging activity was calculated from the following formula:

$$
\% \text { scavenging }[\mathrm{DPPH}]=\left[\left(\mathrm{A}_{0}-\mathrm{A}_{1}\right) / \mathrm{A}_{0}\right] * 100
$$

Where $A_{0}$ was the absorbance of the control and $A_{1}$ was the absorbance in the presence of the samples and standard.

\section{Hydroxyl radical scavenging assay}

The scavenging assay for hydroxyl radical was performed by a standard method [12]. Hydroxyl radical was generated by the Fenton reaction using a $\mathrm{Fe}^{3+}$-ascorbateEDTA- $\mathrm{H}_{2} \mathrm{O}_{2}$ system. The assay quantifies the 2-deoxyribose degradation product, by its condensation with TBA. All tests were carried out six times. Mannitol, a classical. $\mathrm{OH}$ scavenger, was used as a standard compound. Percent inhibition was evaluated by the following equation:

$$
\% \text { inhibition }=\left[\left(\mathrm{A}_{0}-\mathrm{A}_{1}\right) / \mathrm{A}_{0}\right]^{*} 100
$$

Where $A_{0}$ was the absorbance of the control and $A_{1}$ was the absorbance in the presence of the samples and standard.

\section{Superoxide radical scavenging assay}

Measurements of superoxide anion scavenging activities of the samples and standard quercetin were done based on the reduction of NBT according to a previously described method [12]. Superoxide radical is generated by a non-enzymatic system of phenazine methosulfatenicotinamide adenine dinucleotide (PMS/NADH). These radicals reduce nitro blue tetrazolium (NBT) into a purple colored formazan which was measured spectrophotometrically at $\lambda=562 \mathrm{~nm}$. All tests were performed six times. The percentage inhibition of superoxide anion generation was calculated using the following formula:

$$
\% \text { inhibition }=\left[\left(\mathrm{A}_{0}-\mathrm{A}_{1}\right) / \mathrm{A}_{0}\right]^{*} 100
$$

Where $A_{0}$ was the absorbance of the control and $A_{1}$ was the absorbance in the presence of the samples and standard.

\section{Nitric oxide radical scavenging assay}

Sodium nitroprusside (SNP) gives rise to nitric oxide that under interaction with oxygen produce nitrite ions measured by Griess Illosvoy reaction [12]. The chromophore generated was spectrophotometrically measured at $\lambda=$ $540 \mathrm{~nm}$ against blank sample. All tests were performed six times. Curcumin was used as a standard. The percentage inhibition of nitric oxide radical generation was calculated using the following formula:

$$
\% \text { inhibition }=\left[\left(A_{0}-A_{1}\right) / A_{0}\right] * 100
$$

Where $A_{0}$ was the absorbance of the control and $A_{1}$ was the absorbance in the presence of the samples and standard.

\section{Hydrogen peroxide scavenging assay}

FOX-reagent method was used to determine this activity of the sample and the reference compound sodium pyruvate, as previously described [12]. The absorbance of the ferric-xylenol orange complex was measured at $\lambda=560$ $\mathrm{nm}$. All tests were carried out six times. The percentage of scavenging of hydrogen peroxide of fruit extracts and standard compound:

$$
\% \text { scavenged }\left[\mathrm{H}_{2} \mathrm{O}_{2}\right]=\left[\left(\mathrm{A}_{0}-\mathrm{A}_{1}\right) / \mathrm{A}_{0}\right] * 100
$$

where $A_{0}$ was the absorbance of the control, and $A_{1}$ was the absorbance in the presence of the sample of fruit extracts and standard.

\section{Peroxynitrite scavenging assay}

Peroxynitrite (ONOO-) synthesis was done $12 \mathrm{hrs}$ before the assay, according to Beckman et al [14]. Acidic solution $(0.6 \mathrm{M} \mathrm{HCl})$ of $5 \mathrm{ml} \mathrm{H} \mathrm{O}_{2}(0.7 \mathrm{M})$ was mixed with 5 $\mathrm{ml}$ of $0.6 \mathrm{M} \mathrm{KNO}_{2}$ on an ice bath for $1 \mathrm{~s}$ and $5 \mathrm{ml}$ of icecold 1.2 $\mathrm{M} \mathrm{NaOH}$ was added to the reaction mixture. Excess $\mathrm{H}_{2} \mathrm{O}_{2}$ was adsorbed by granular $\mathrm{MnO}_{2}$ and the reaction mixture was left at $-20^{\circ} \mathrm{C}$. The concentration of the peroxynitrite solution was measured spectrophotometrically at $\lambda=302 \mathrm{~nm}\left(\varepsilon=1670 \mathrm{M}^{-1} \mathrm{~cm}^{-1}\right)$.

Evans blue bleaching assay was used to measure the peroxynitrite scavenging activity [12]. The percentage of scavenging of $\mathrm{ONOO}^{-}$was calculated by comparing the results of the test and blank samples. All tests were performed six times. Gallic acid was used as reference compound. The percentage of scavenging of peroxynitrite anion was calculated using the following equation:

$$
\% \text { scavenged }\left[\mathrm{ONOO}^{-}\right]=\left[\left(\mathrm{A}_{0}-\mathrm{A}_{1}\right) / \mathrm{A}_{0}\right] * 100
$$

where $A_{0}$ was the absorbance of the control, and $A_{1}$ was the absorbance in the presence of the sample of fruit extracts and standard. 


\section{Singlet oxygen scavenging assay}

Singlet oxygen $\left({ }^{1} \mathrm{O}_{2}\right)$ production, and at the same time, its scavenging by the samples and the reference compound lipoic acid can be monitored by $N, N$-dimethyl-4nitrosoaniline (RNO) bleaching, using a earlier reported method [12]. Singlet oxygen was generated by a reaction between $\mathrm{NaOCl}$ and $\mathrm{H}_{2} \mathrm{O}_{2}$ and the bleaching of $\mathrm{RNO}$ was read at $\lambda=440 \mathrm{~nm}$. All tests were performed six times. Singlet oxygen scavenging was calculated by the following formula:

$$
\% \text { of scavenging }=\left[\left(A_{0}-A_{1}\right) / A_{0}\right] * 100
$$

where $A_{0}$ was the absorbance of the control, and $A_{1}$ was the absorbance in the presence of the sample of fruit extracts and standard.

\section{Hypochlorous acid scavenging assay}

According to a previously described method [12], hypochlorous acid $(\mathrm{HOCl})$ was prepared just before the experiment by adjusting the $\mathrm{pH}$ of a $10 \%(\mathrm{v} / \mathrm{v})$ solution of $\mathrm{NaOCl}$ to $\mathrm{pH} 6.2$ with $0.6 \mathrm{M} \mathrm{H}_{2} \mathrm{SO}_{4}$ and the concentration of $\mathrm{HOCl}$ was determined by taking the absorbance at $\lambda=235 \mathrm{~nm}$ using the molar extinction coefficient of 100 $\mathrm{M}^{-1} \mathrm{~cm}^{-1}$. The scavenging activities of the fruit extracts and the standard, ascorbic acid, a potent $\mathrm{HOCl}$ scavenger was evaluated by measuring the decrease in the absorbance of catalase at $\lambda=404 \mathrm{~nm}$. All tests were performed six times. The percentage of scavenging of $\mathrm{HOCl}$ was calculated using the following equation:

$\%$ scavenged $[\mathrm{HOC} 1]=\left[\left(\mathrm{A}_{0}-\mathrm{A}_{1}\right) / \mathrm{A}_{0}\right] * 100$

where $A_{0}$ was the absorbance of the control, and $A_{1}$ was the absorbance in the presence of the sample of fruit extracts and standard.

\section{Reducing power assay}

The $\mathrm{Fe}^{3+}$-reducing power of the extract was determined by a standard method [12]. In a phosphate buffer solution (0.2 M, pH 6.6), different concentrations (0.0-0.4 mg/ml) of the extract were mixed with potassium hexacyanoferrate $(0.1 \%)$, followed by incubation. After incubation, the upper portion of the solution was diluted, and $\mathrm{FeCl}_{3}$ solution $(0.01 \%)$ was added. The reaction mixture was left for $10 \mathrm{~min}$ at room temperature for colour development and the absorbance was measured at $\lambda=700 \mathrm{~nm}$. All tests were performed six times. A higher absorbance of the reaction mixture indicated greater reducing power. Ascorbic acid was used as a positive control.

\section{Determination of total phenolic content}

The amount of total phenolics present in the fruit extract was determined using Folin-Ciocalteu (FC) reagent by a formerly reported method [12]. A gallic acid standard curve $\left(R^{2}=0.9468\right)$ was used to measure the phenolic content.

\section{Determination of total flavonoid content}

The amount of total flavonoids was determined with aluminium chloride $\left(\mathrm{AlCl}_{3}\right)$ according to a known method [12]. The flavonoid content was calculated from quercetin standard curve $\left(R^{2}=0.9947\right)$.

\section{Determination of ascorbic acid content}

The amount of total ascorbic acid was determined with ferroin complexation method with minor modification [15]. To $1 \mathrm{ml}$ solution of the sample, $100 \mu \mathrm{l}$ of $3.3^{*} 10^{-3} \mathrm{M}$ Iron (III)-phen colour reagent was added and the $\mathrm{pH}$ was adjusted to 4.5 with $20 \%$ sodium acetate. The absorbance was measured at $\lambda=512 \mathrm{~nm}$ and subsequently the ascorbate content was calculated from ascorbic acid standard curve $\left(R^{2}=0.9554\right)$.

\section{In vivo Antioxidant assay}

\section{Experimental design}

Mice were randomly divided into ten groups containing six animals in each group. Group I animals served as control and administered a single daily dose of normal saline. Groups II, III and IV received the T. chebula extract at a dose of 10,50 and $100 \mathrm{mg} / \mathrm{kg}$ body weight, respectively. Groups V, VI and VII were given T. belerica extract at a dose of 10,50 and $100 \mathrm{mg} / \mathrm{kg}$ body weight, respectively. The other three groups (Group VIII, IX and X) were administered E. officinalis extract at the same dose. The treatments were carried out orally for 7 days and on the 8 th day all the animals were sacrificed by cervical dislocation. The liver was immediately removed and after washing with ice-cold saline it was homogenized in 10 volume of $0.1 \mathrm{M}$ phosphate buffer ( $\mathrm{pH}$ 7.4) containing $5 \mathrm{mM}$ EDTA and $0.15 \mathrm{M} \mathrm{NaCl}$, and centrifuged at $8000 \mathrm{~g}$ for 30 min at $4^{\circ} \mathrm{C}$. The supernatant was collected and used for the assay of enzyme activities. Protein concentration was estimated according to Lowry method [16] using BSA as standard.

\section{Assay of Antioxidant Enzymes}

Superoxide dismutase (SOD) was assayed by measuring the inhibition of the formation of blue colored formazan at $560 \mathrm{~nm}$ according to the technique of Kakkar et al. [17]. Catalase (CAT) activity was measured by following the decrease in $\mathrm{H}_{2} \mathrm{O}_{2}$ concentration spectrophotometrically over time at $240 \mathrm{~nm}$ according to a previously described method [18]. Glutathione-S-transferase (GST) was determined by the method of Habig and Jacoby [19] based on the formation of GSH-CDNB conjugate and increase in the absorbance at $340 \mathrm{~nm}$. Reduced glutathione (GSH) level was measured spectrophotometrically at $412 \mathrm{~nm}$ by the method of Ellman [20]. 

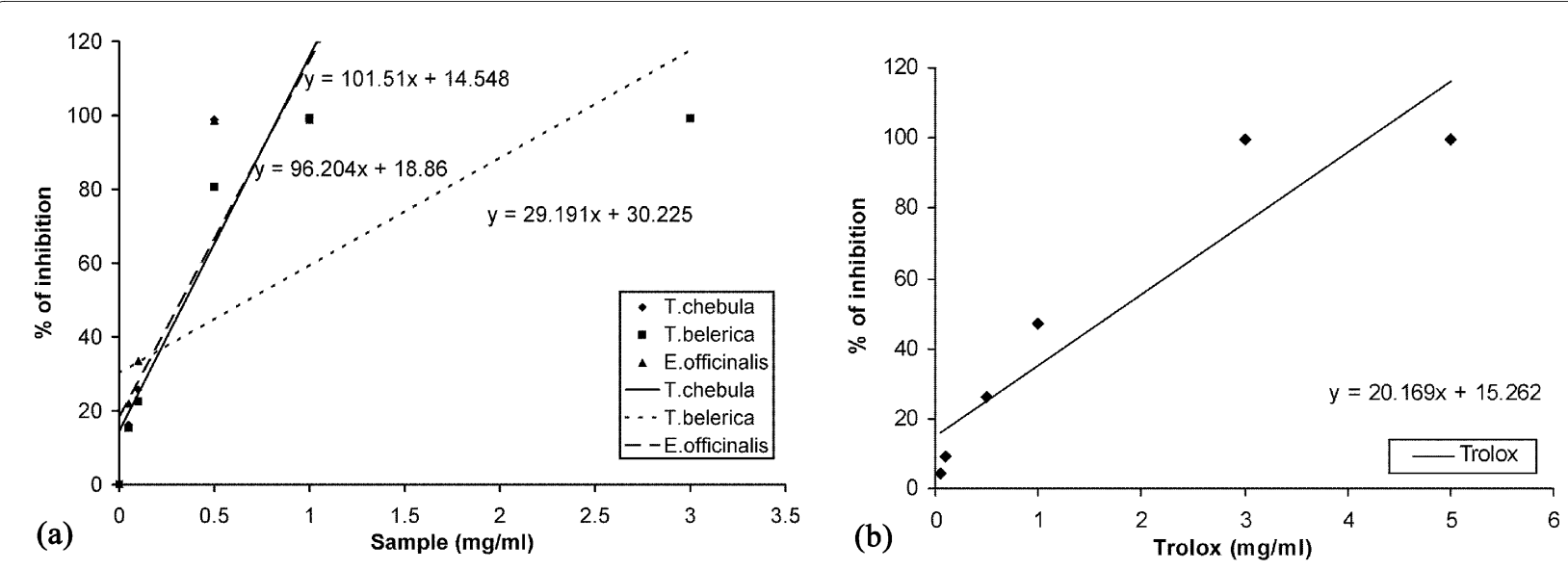

Figure 1 Total antioxidant activity. Total antioxidant activity of plant extract and trolox. Effect of (a) T. chebula, T. belerica and E. officinalis extracts and $(b)$ reference compound trolox on ABTS radical cation decolorization assay. The percentage of inhibition was plotted against concentration of sample. All data are expressed as mean \pm S.D. $(n=6)$.

Table 2: Comparison of the antioxidant and free radical scavenging capacities of $70 \%$ methanolic crudes of Terminalia chebula, Terminalia belerica and Emblica officinalis

\begin{tabular}{|c|c|c|c|}
\hline Name of Assay & $70 \%$ methanolic crudes of & Standard & $\begin{array}{l}\text { Values of } \\
\text { Standard } \\
\text { compounds }\end{array}$ \\
\hline
\end{tabular}

Terminalia chebula Terminalia belerica Emblica officinalis

\begin{tabular}{|c|c|c|c|c|c|}
\hline TEAC Values & $4.52 \pm 0.12$ & $1.01 \pm 0.03$ & $4.10 \pm 0.17$ & -- & -- \\
\hline † Phenolic content & $127.60 \pm 0.001$ & $133.00 \pm 0.003$ & $215.60 \pm 0.004$ & -- & -- \\
\hline ‡ Flavonoid content & $219.30 \pm 0.01$ & $138.30 \pm 0.01$ & $176.00 \pm 0.01$ & -- & -- \\
\hline$\S$ Ascorbic acid content & $46.74 \pm 1.10$ & $45.25 \pm 0.75$ & $71.08 \pm 1.63$ & -- & -- \\
\hline
\end{tabular}

? IC 50 values of the extracts for free radical scavenging capacity for:

\begin{tabular}{lccccc}
\hline DPPH & $1.73 \pm 0.07^{* * *}$ & $1.45 \pm 0.02^{* * *}$ & $1.43 \pm 0.03^{* * *}$ & Ascorbic acid & $5.29 \pm 0.28$ \\
Hydroxyl $(\mathrm{OH} \cdot)$ & $72.02 \pm 8.99^{* * *}$ & $203.25 \pm 1.87^{* *}$ & $382.02 \pm 7.88^{* * *}$ & Mannitol & $571.45 \pm 20.12$ \\
Superoxide $\left(\mathrm{O}_{2} \cdot\right)$ & $13.42 \pm 0.22^{* * *}$ & $18.18 \pm 1.39^{* * *}$ & $13.82 \pm 0.19^{* * *}$ & Quercetin & $42.06 \pm 1.35$ \\
Nitric oxide $(\mathrm{NO})$ & $33.28 \pm 4.56^{* * *}$ & $40.83 \pm 4.40^{* * *}$ & $33.89 \pm 2.94^{* * *}$ & Curcumin & $90.82 \pm 4.75$ \\
Peroxynitrite $(\mathrm{ONOO}-)$ & $1.27 \pm 0.07^{* * *}$ & $0.99 \pm 0.10^{* *}$ & $0.83 \pm 0.03^{\mathrm{NS}}$ & Gallic acid & $0.88 \pm 0.06$ \\
Singlet oxygen $\left(1 \mathrm{O}_{2}\right)$ & $424.50 \pm 24.70^{* * *}$ & $233.12 \pm 48.68^{* * *}$ & $490.42 \pm 159.59^{* *}$ & Lipoic acid & $46.15 \pm 1.16$ \\
Hypochlorous acid $(\mathrm{HOCl})$ & $433.60 \pm 15.45^{* *}$ & $271.51 \pm 13.70^{* *}$ & $420.58 \pm 31.97^{* * *}$ & Ascorbic acid & $235.96 \pm 5.75$ \\
\hline
\end{tabular}

† Phenolic content $(\mathrm{mg} / \mathrm{ml}$ Gallic acid equivalent per $100 \mathrm{mg}$ plant extract)

\# Flavonoid content $(\mathrm{mg} / \mathrm{ml}$ Quercetin equivalent per $100 \mathrm{mg}$ plant extract)

$\S$ Ascorbic acid content ( $\mathrm{mg} / \mathrm{ml}$ Ascorbic acid per $100 \mathrm{mg}$ plant extract)

? IC 50 Values are in $\mu \mathrm{g} / \mathrm{ml}$ (except for Peroxynitrite scavenging assay where values are expressed in $\mathrm{mg} / \mathrm{ml}$ ). Each value represents mean \pm S.D. $(\mathrm{n}$ $=6)$

${ }^{*} \mathrm{p}<0.05 ;{ }^{* *} \mathrm{p}<0.01 ; * * *<<0.001 ; \mathrm{NS}=$ Non significant 


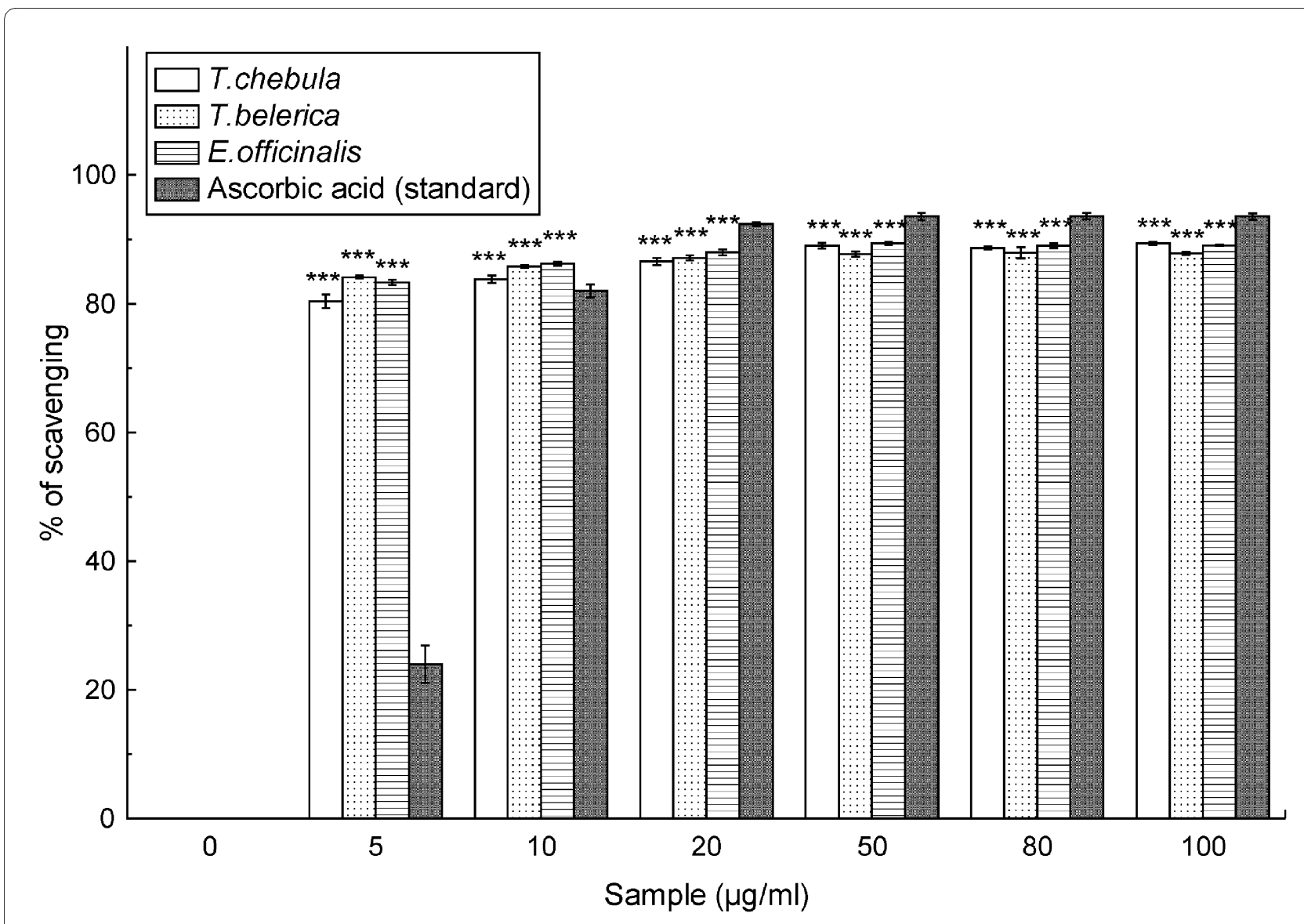

Figure 2 DPPH scavenging activity. Effect of the T. chebula, T. belerica and E. officinalis extracts and standard ascorbic acid on DPPH radical scavenging study. The data is expressed as \% scavenging of DPPH radicals. The results are mean \pm S.D. of six parallel measurements. ${ }^{* *} \mathrm{p}<0.001 \mathrm{vs} 0 \mu \mathrm{g} / \mathrm{ml}$.

\section{Statistical analysis}

All data were reported as the mean \pm SD of six measurements. The statistical analysis was performed by KyPlot version 2.0 beta 15 (32 bit). The $\mathrm{IC}_{50}$ values were calculated by the formula, $\mathrm{Y}=100 * \mathrm{~A} 1 /(\mathrm{X}+\mathrm{A} 1)$ where $\mathrm{A} 1=$ $\mathrm{IC}_{50}, \mathrm{Y}=$ response $(\mathrm{Y}=100 \%$ when $\mathrm{X}=0), \mathrm{X}=$ inhibitory concentration. $\mathrm{The} \mathrm{IC}_{50}$ values were compared by paired $\mathrm{t}$ test (two-sided). $p<0.05$ was considered significant.

\section{Results}

Total antioxidant activity

The total antioxidant capacity of the extract was calculated from the decolorization of ABTS.+, upon interaction with the extract or standard trolox that suppressed the absorbance of the ABTS ++ radical cation and the results, expressed as percentage inhibition of absorbance, are shown in Figure 1(a) and 1(b), respectively. The TEAC value of the extracts of T. chebula, T. belerica and E. officinalis were $4.52 \pm 0.12,1.01 \pm 0.03$ and $4.10 \pm 0.17$, respectively.

\section{DPPH Scavenging Activity}

As is evident in the Figure 2 and the $\mathrm{IC}_{50}$ value of the samples, following the order T. chebula, T. belerica \&E. officinalis $(1.73 \pm 0.07 \mu \mathrm{g} / \mathrm{ml}, 1.45 \pm 0.02 \mu \mathrm{g} / \mathrm{ml} \& 1.43 \pm 0.03$ $\mu \mathrm{g} / \mathrm{ml})$ in comparison to the ascorbic acid $(5.29 \pm 0.28 \mu \mathrm{g} /$ $\mathrm{ml}$ ) standard (Table 2) to scavenge the radical, it can be put forward as a fact that the extracts truly work as antioxidant.

\section{Hydroxyl radical scavenging assay}

This assay shows the abilities of the extracts and standard mannitol to scavenge hydroxyl radical, as shown in Figure 3. The $\mathrm{IC}_{50}$ values (Table 2 ) of the extracts (in the order $T$. chebula, T. belerica and E. officinalis) and standard in this assay were $72.02 \pm 8.99 \mu \mathrm{g} / \mathrm{ml}, 203.25 \pm 1.87 \mu \mathrm{g} / \mathrm{ml}$, $382.02 \pm 7.88 \mu \mathrm{g} / \mathrm{ml}$ and $571.45 \pm 20.12 \mu \mathrm{g} / \mathrm{ml}$, respectively.

\section{Superoxide radical scavenging assay}

Figure 4 shows the abilities of the fruit extracts and the reference compound quercetin to quench superoxide radicals in the PMS-NADH reaction mixture. The $\mathrm{IC}_{50}$ val- 


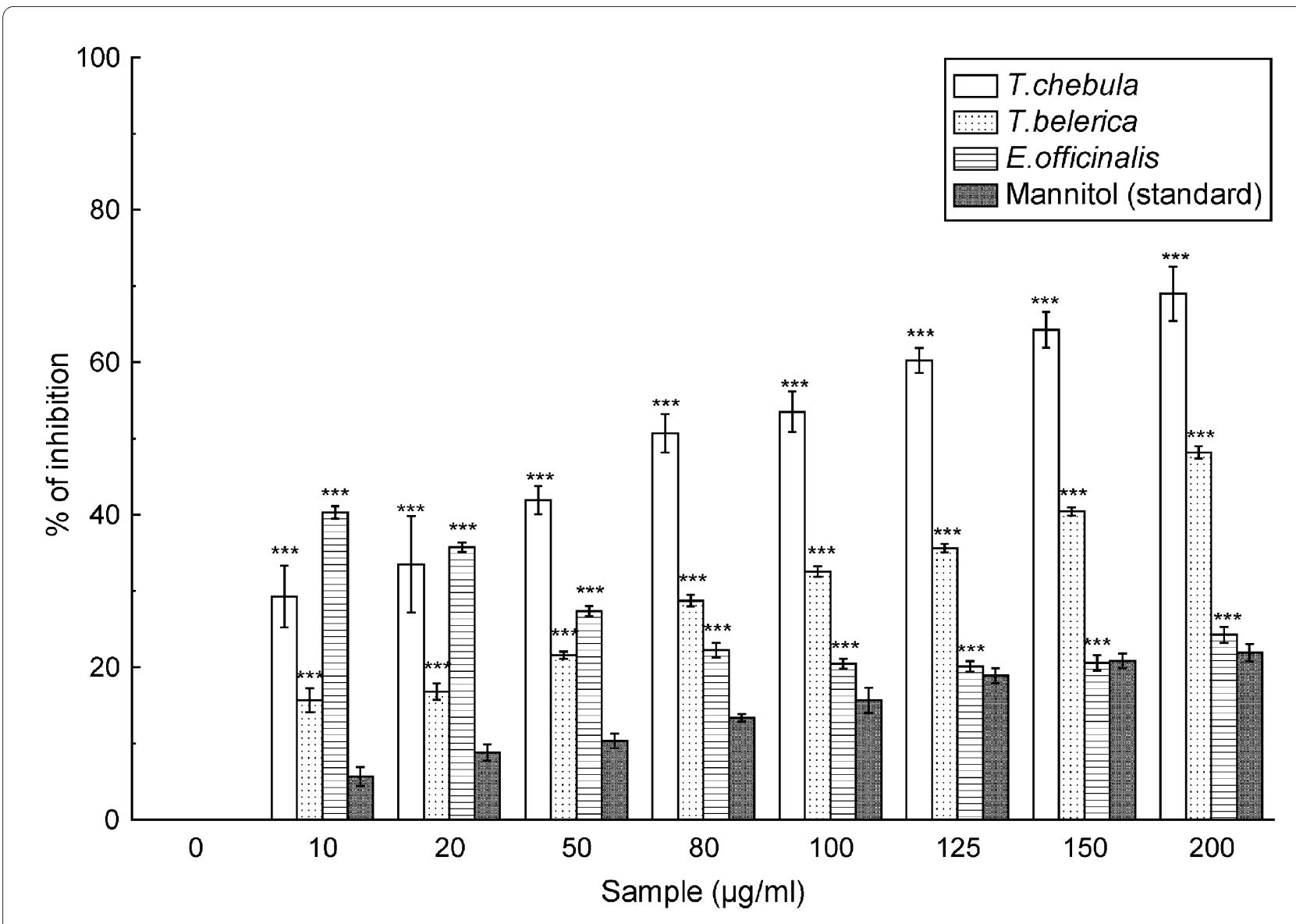

Figure 3 Hydroxyl radical scavenging assay. Hydroxyl radical scavenging activity of the T. chebula, T. belerica and E. officinalis extracts and the reference compound mannitol. The data represent the percentage of inhibition of deoxyribose degradation. The results are mean \pm S.D. of six parallel measurements. ${ }^{* * *} p<0.001 \mathrm{vs} 0 \mu \mathrm{g} / \mathrm{ml}$.

ues (Table 2) of the fruit extracts, in the order as mentioned above and quercetin were $13.42 \pm 0.22 \mu \mathrm{g} / \mathrm{ml}$, $18.18 \pm 1.39 \mu \mathrm{g} / \mathrm{ml}, 13.82 \pm 0.19 \mu \mathrm{g} / \mathrm{ml}$ and $42.06 \pm 1.35$ $\mu \mathrm{g} / \mathrm{ml}$, respectively.

\section{Nitric oxide radical scavenging assay}

As evident from Figure 5, the extracts of T. chebula, T. belerica and E. officinalis also caused considerable dosedependent scavenging of nitric oxide in comparison to the reference compound curcumin, which is also reflected in their respective $\mathrm{IC}_{50}$ values (Table 2) of 33.28 $\pm 4.56 \mu \mathrm{g} / \mathrm{ml}, 40.83 \pm 4.40 \mu \mathrm{g} / \mathrm{ml}, 33.89 \pm 2.94 \mu \mathrm{g} / \mathrm{ml}$ and $90.82 \pm 4.75 \mu \mathrm{g} / \mathrm{ml}$ for the extracts in the aforesaid order and curcumin.

\section{Peroxynitrite scavenging assay}

Figure 6 shows the peroxynitrite scavenging activity of the fruit extracts in a concentration dependent manner. The calculated $\mathrm{IC}_{50}$ values for $T$. chebula, T. belerica and E. officinalis were $1.27 \pm 0.07 \mathrm{mg} / \mathrm{ml}, 0.99 \pm 0.10 \mathrm{mg} / \mathrm{ml}$ and $0.83 \pm 0.03 \mathrm{mg} / \mathrm{ml}$, repectively in comparison to that of the reference compound gallic acid $\left(\mathrm{IC}_{50}=0.88 \pm 0.06\right.$ $\mathrm{mg} / \mathrm{ml}$ ) (Table 2) indicating that the samples are not as potent scavenger of peroxynitrite as gallic acid, except $E$. officinalis.

\section{Hydrogen peroxide scavenging assay}

Hydrogen peroxide scavenging activity of the extracts of T. chebula, T. belerica and E. officinalis showed no substantial result compared to the standard sodium pyruvate $\left(\mathrm{IC}_{50}=3.24 \pm 0.30 \mathrm{mg} / \mathrm{ml}\right)$ and the $\mathrm{IC}_{50}$ values of the same were found to be much higher than can be represented. So, no figure or $\mathrm{IC}_{50}$ values were provided.

\section{Singlet oxygen scavenging assay}

The T. chebula, T. belerica and E. officinalis extracts also showed a moderate dose-dependent scavenging effect of singlet oxygen species with $\mathrm{IC}_{50}$ values (Table 2) of 424.50 $\pm 24.70 \mu \mathrm{g} / \mathrm{ml}, 233.12 \pm 48.68 \mu \mathrm{g} / \mathrm{ml}$ and $490.42 \pm 159.59$ $\mu \mathrm{g} / \mathrm{ml}$, respectively (Figure 7 ). Lipoic acid was used as a 


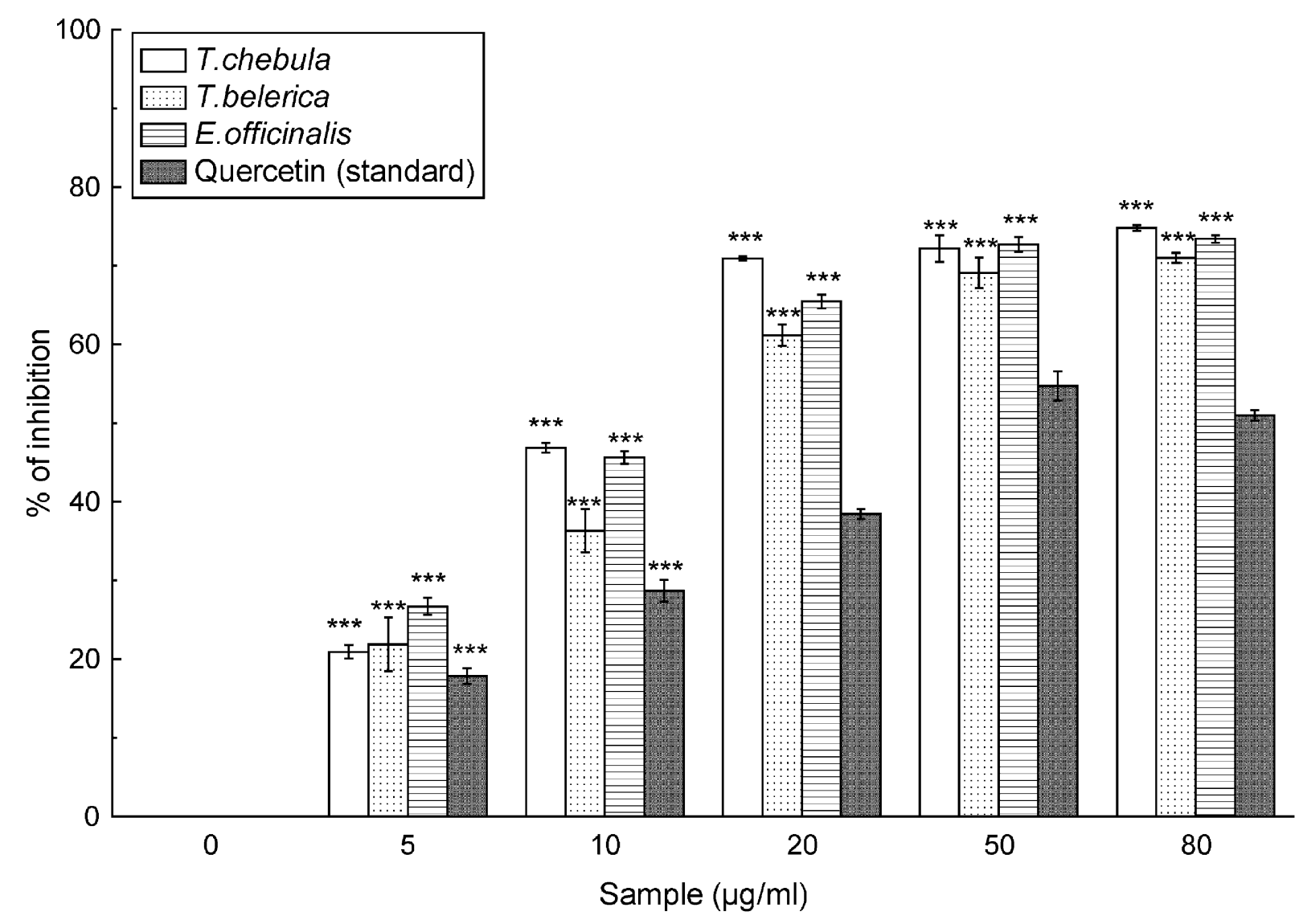

Figure 4 Superoxide radical scavenging assay. Scavenging effect of T. chebula, T. belerica and E. officinalis plant extracts and standard quercetin on superoxide radical. The data represents the percentage of superoxide radical inhibition. All data are expressed as mean \pm S.D. $(n=6)$. ${ }^{* *} p<0.001$ vs $0 \mu \mathrm{g} / \mathrm{ml}$

reference compound and $46.15 \pm 1.16 \mu \mathrm{g} / \mathrm{ml}$ lipoic acid was needed for $50 \%$ inhibition.

\section{Hypochlorous acid scavenging assay}

Figure 8 shows how effectively the T. chebula, T. belerica and E. officinalis extracts dose-dependently scavenge hypochlorous acid compared to that of ascorbic acid. The $50 \%$ inhibition concentration values of the extracts in the above order $\left(\mathrm{IC}_{50}=433.60 \pm 15.45 \mu \mathrm{g} / \mathrm{ml}, 271.51 \pm 13.70\right.$ $\mu \mathrm{g} / \mathrm{ml}, 420.58 \pm 31.97 \mu \mathrm{g} / \mathrm{ml})$ and ascorbic acid $\left(\mathrm{IC}_{50}=\right.$ $235.96 \pm 5.75 \mu \mathrm{g} / \mathrm{ml}$ ) as seen in Table 2 also corroborates the data.

\section{Reducing power assay}

As illustrated in Figure 9, $\mathrm{Fe}^{3+}$ to $\mathrm{Fe}^{2+}$ transformation in the presence of T. chebula, T. belerica and E. officinalis extracts and reference compound ascorbic acid was performed to measure the reductive capability. Throughout the concentration range $(0.0-1.0 \mathrm{mg} / \mathrm{ml})$, the fruits extracts and the standard showed nearly the same trend in their reductive capability, although all the extracts exhibiting lower activity than the standard.

\section{Determination of total phenolic, flavonoid and ascorbic acid content}

The phenolic and flavonoid compounds along with the subsequent ascorbic acid contents of the extracts may contribute directly to antioxidative action. The total phenolic content of $70 \%$ methanolic extracts of T. chebula, $T$. belerica and E. officinalis were $127.60 \pm 0.001 \mathrm{mg} / \mathrm{ml}$, $133.00 \pm 0.003 \mathrm{mg} / \mathrm{ml}$ and $215.60 \pm 0.004 \mathrm{mg} / \mathrm{ml}$ gallic acid equivalent per $100 \mathrm{mg}$ fruit extract, respectively, whereas the flavonoid contents were $219.30 \pm 0.01 \mathrm{mg} /$ $\mathrm{ml}, 138.30 \pm 0.01 \mathrm{mg} / \mathrm{ml}, 176.00 \pm 0.01 \mathrm{mg} / \mathrm{ml}$ quercetin per $100 \mathrm{mg}$ fruit extract, following the above order. In case of the ascorbic acid content determination, $46.74 \pm$ $1.10 \mathrm{mg} / \mathrm{ml}, 45.25 \pm 0.75 \mathrm{mg} / \mathrm{ml}$ and $71.08 \pm 1.63 \mathrm{mg} / \mathrm{ml}$ ascorbic acid were found to be present in $100 \mathrm{mg}$ fruit extracts of T. chebula, T. belerica and E. officinalis, respectively. 


\section{Correlation between the total phenolic or flavonoid contents with the antioxidant activity}

As showed in Figure 10(a), the total phenolic content of $E$. officinalis significantly correlated with antioxidant activity $(R=0.9972, p<0.05)$, whereas the correlation coefficients for T. chebula and T. belerica were found to be greater than $0.9(R=0.9960$ and $R=0.9921$ respectively with $p>0.05)$ which proved that the phenolic contents of these plants highly attributed their antioxidant activity. The correlation coefficient of $T$. chebula for flavonoid contents with its antioxidant capacity was highly significant $(R=0.9990, p<0.05)$, whereas the flavonoid contents of T. belerica and E. officinalis were highly $(R=$ $0.9219, p>0.05)$ and reasonably $(R=0.8914, p>0.05)$ correlated with their antioxidant activity (Figure 10(b)). In general, the results showed that the total phenolic and flavonoid content in individual fruits was highly correlated with antioxidant activity.

\section{Effect on Enzyme Activity}

In order to investigate whether these antioxidant activities of fruit extracts are mediated by an increase in anti- oxidant enzymes, the activities of SOD, CAT, GST and GSH (Table 3) were measured individually for the three plants through oral administration in mice. The activity of SOD is significantly enhanced by all three fruit extracts in a dose dependent manner. With the increasing doses of the fruit extracts, the CAT activity was also increased for each plant, in comparison to the control, as is evident from the results. The results also showed that there was a considerable dose-dependent effect of the fruit extracts in the gradual enhancement of the GST activity in the treated mice than the control ones. Similarly, we find a gradual increase in the GSH activity procured by the fruit extracts with their increasing concentrations for the dose treated mice compared to the control.

\section{Discussion}

Antioxidants are compounds that prevent the oxidation of essential biological macromolecules by inhibiting the propagation of the oxidizing chain reaction. Keeping in mind the adverse effects of synthetic antioxidants, researchers have channelled their interest in isolating

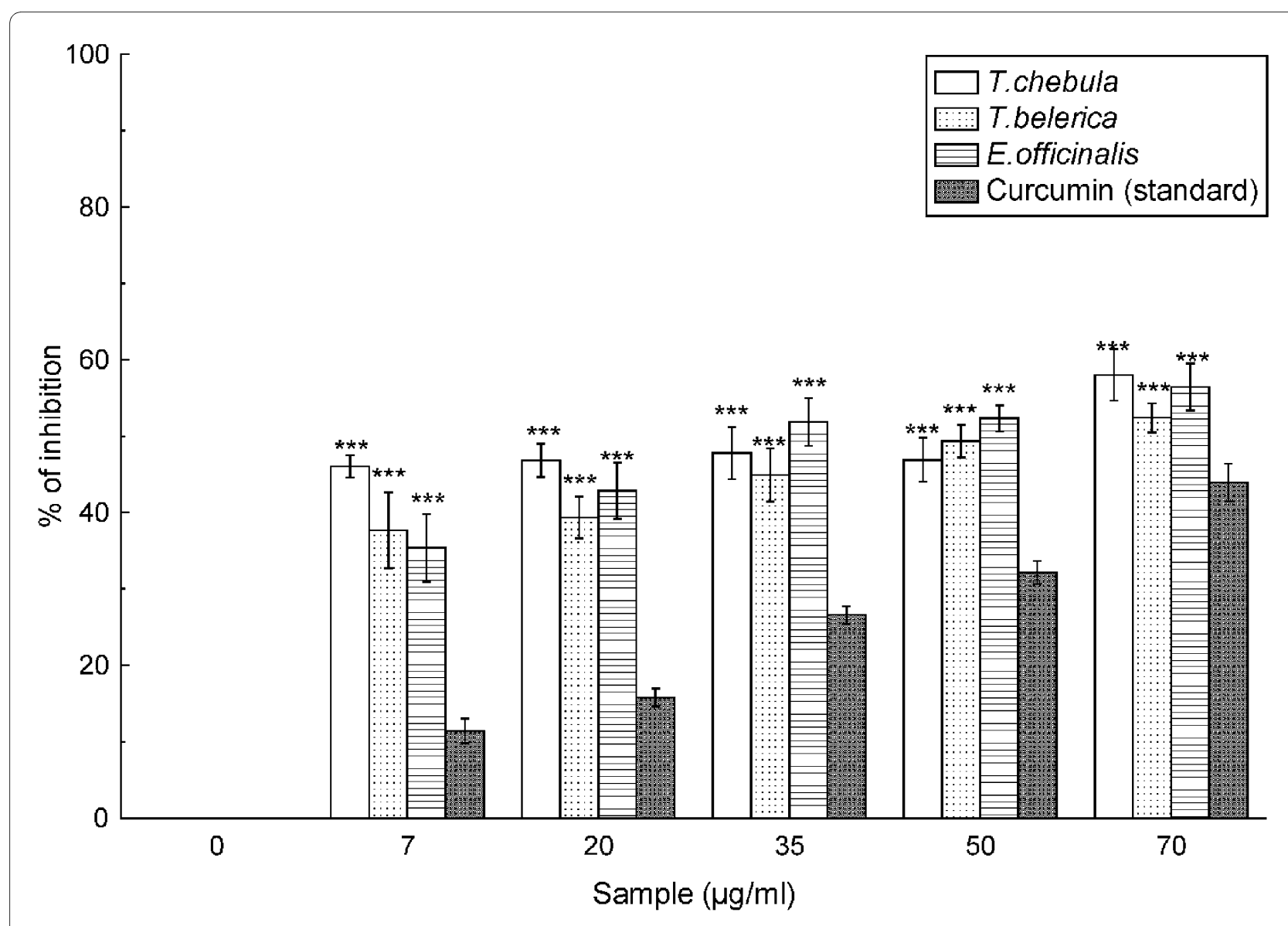

Figure 5 Nitric oxide radical scavenging assay. The nitric oxide radical scavenging activity of T. chebula, T. belerica and E. officinalis extracts and standard curcumin. The data represents the $\%$ of nitric oxide inhibition. Each value represents mean \pm S.D. $(n=6) .{ }^{* *} p<0.001 \mathrm{vs} 0 \mu \mathrm{g} / \mathrm{ml}$. 


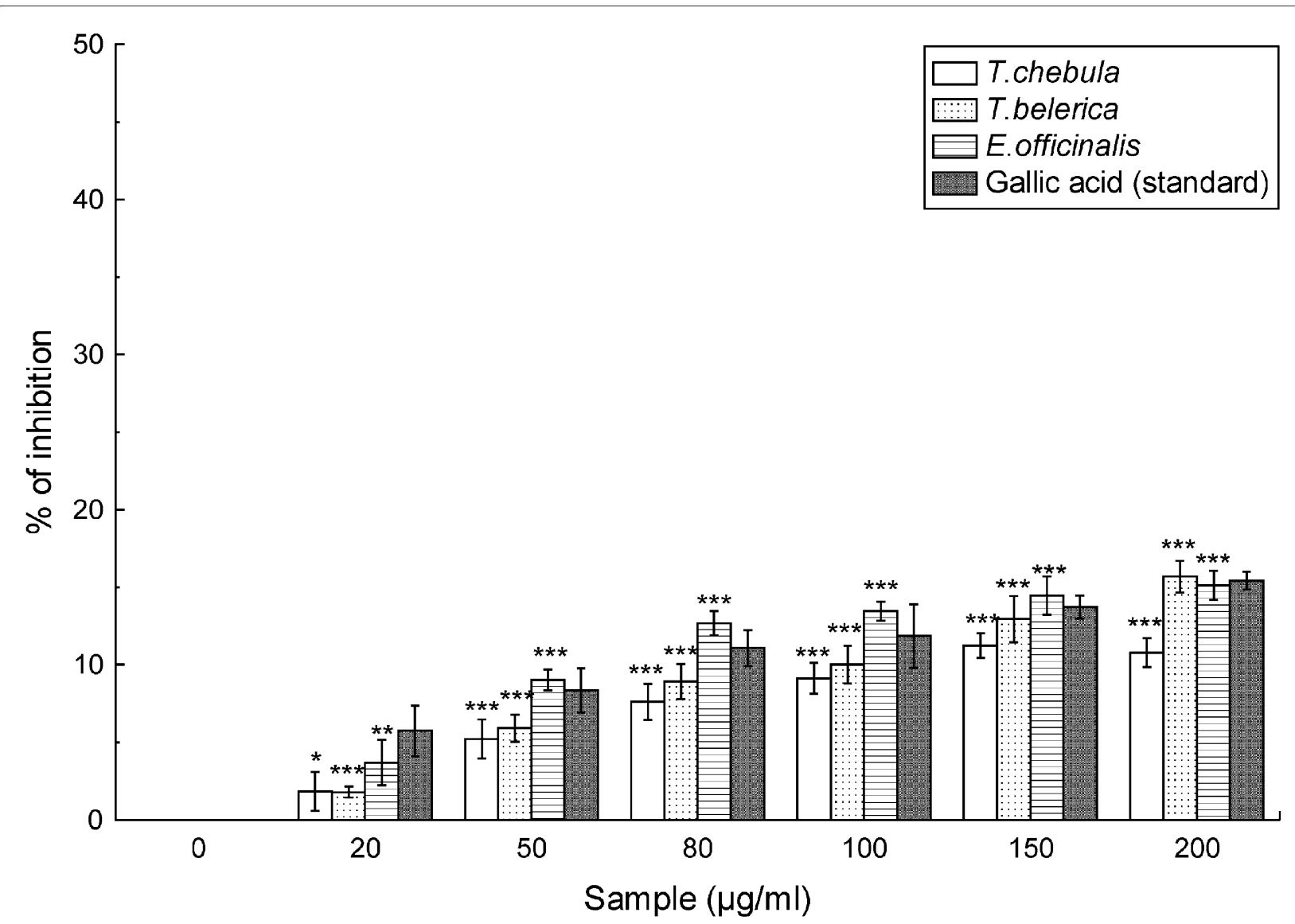

Figure 6 Peroxynitrite anion scavenging assay. The peroxynitrite anion scavenging activity of T. chebula, T. belerica and E. officinalis plant extracts and standard gallic acid. Each value represents mean \pm S.D. $(n=6) .{ }^{*} p<0.05,{ }^{* *} p<0.01$ and ${ }^{* * *} p<0.001 \mathrm{vs} 0 \mu \mathrm{g} / \mathrm{ml}$.

natural antioxidants [21] which are very effective to control the oxidative stress and hence prevent the initiation of disease propagation. Interestingly, quite a few studies on the antioxidant properties of the three plant materials, viz., T. chebula [22,23], T. belerica [24,25] and E. officinalis $[26,27]$ have been done earlier. However, this study provides a definitive report about the free radical scavenging capacity of T. chebula, T. belerica and E. officinalis, since the antioxidant activity of a drug may depend on the free radical scavenging activity [28].

ABTS + is a blue colored chromophore which is reduced to ABTS on a concentration dependant manner upon addition of the fruit extract. The results are compared with trolox and the TEAC value demonstrates the extracts as a potent antioxidant, with their TEAC values following the order T. chebula $>$ E. officinalis $>T$. belerica . The effect of the fruit extract in the scavenging assay of $\mathrm{DPPH}$ radical furthermore assured the fact that the extracts smoothly act as antioxidants, since the study on TEAC and DPPH scavenging can be observed as comple- mentary to each other [29], although it followed the order $T$. belerica $>$ E. officinalis $>T$. chebula.

The most detrimental of the free radicals formed in biological systems is the hydroxyl radical that causes enormous damage on biomolecules of the living cells [30]. As the extracts or standard mannitol is added to the Fenton reaction mixture the hydroxyl radicals are scavenged and thereby sugar damage can be blocked. The results, as can be found from Figure 3 and Table 2, indicate that the fruit extracts are better hydroxyl radical scavengers than standard mannitol, with $T$. chebula being the best in comparison to T. belerica and E. officinalis.

Superoxide anion is also another harmful reactive oxygen species as it damages cellular components in biological systems [31]. The ability of the fruit extracts and the reference compound quercetin to quench superoxide radicals from reaction mixture is reflected in the decrease of the absorbance at $\lambda=560 \mathrm{~nm}$. From the results (Figure 4 \& Table 2), it can be put forward that the fruit extracts are more potent scavenger of superoxide radical than the 


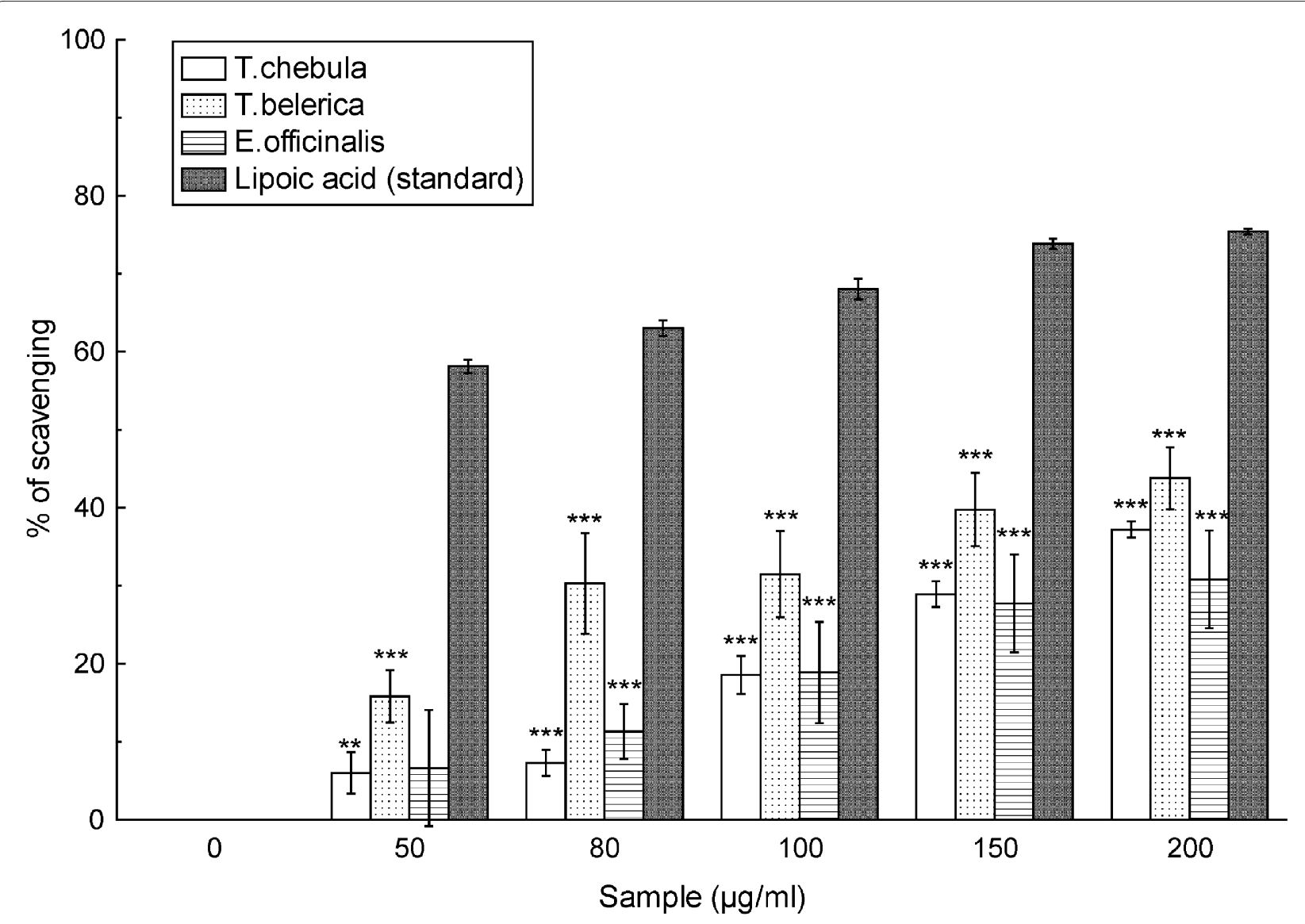

Figure 7 Singlet oxygen scavenging assay. Effect of T. chebula, T. belerica and E. officinalis plant extracts and standard lipoic acid on the scavenging of singlet oxygen. The results are mean \pm S.D. of six parallel measurements. ${ }^{* *} p<0.01$ and ${ }^{* * *} p<0.001 \mathrm{vs} 0 \mu \mathrm{g} / \mathrm{ml}$.

standard quercetin with a decreasing order of T. chebula $>$ E. officinalis $>$ T. belerica.

Nitric oxide radicals play important roles in various types of inflammatory conditions including juvenile diabetes, multiple sclerosis, arthritis and ulcerative colitis $[32,33]$. The nitric oxide generated from sodium nitroprusside reacts with oxygen to form nitrite anion that is well restrained by the extracts. The scavenging activities of the extracts and curcumin proved that the nitric oxide scavenging activity of the former is better than the latter, with $T$. chebula and $E$. officinalis showing nearly the same activity, which is better that that of T. belerica.

Furthermore, the lethal consequence of NO increases significantly upon reaction with superoxide radical resulting in the formation of highly reactive peroxynitrite anion $\left(\mathrm{ONOO}^{-}\right)$, especially its protonated form, peroxynitrous acid (ONOOH). ONOO- has added to the pathogenesis of diseases such as heart disease, Alzheimer's disease, and atherosclerosis [34,35]. However, as revealed in Figure 6, highly considerable results were obtained for the scavenging effects of the studied extracts, which illustrated similar result to the standard gallic acid in the order E. officinalis $>T$. belerica $>T$. chebula.

Hydrogen peroxide is a weak oxidizing agent and can inactivate a few enzymes directly, usually by oxidation of essential thiol (-SH) groups. It can cross cell membrane rapidly, once inside the cell, $\mathrm{H}_{2} \mathrm{O}_{2}$ can probably react with $\mathrm{Fe}^{2+}$ and possibly $\mathrm{Cu}^{2+}$ ions to form hydroxyl radical and this may be the origin of many of its toxic effects [36]. From the results, it appeared that $\mathrm{H}_{2} \mathrm{O}_{2}$ scavenging activity of the fruit extracts is very negligible compared to standard sodium pyruvate.

A high energy form of oxygen, singlet oxygen is generated in the skin upon UV-radiation and it induces hyperoxidation, oxygen cytotxicity and decreases the antioxidant activity [37]. The higher $\mathrm{IC}_{50}$ values (Table 2) of the studied extracts than the reference compound lipoic acid indicated that the extracts of the fruits of $T$. chebula, T. belerica and E. officinalis, with T. belerica being the most effective among them, have singlet oxygen scavenging activity but poor compared to standard lipoic acid, as also found in Figure 7. 


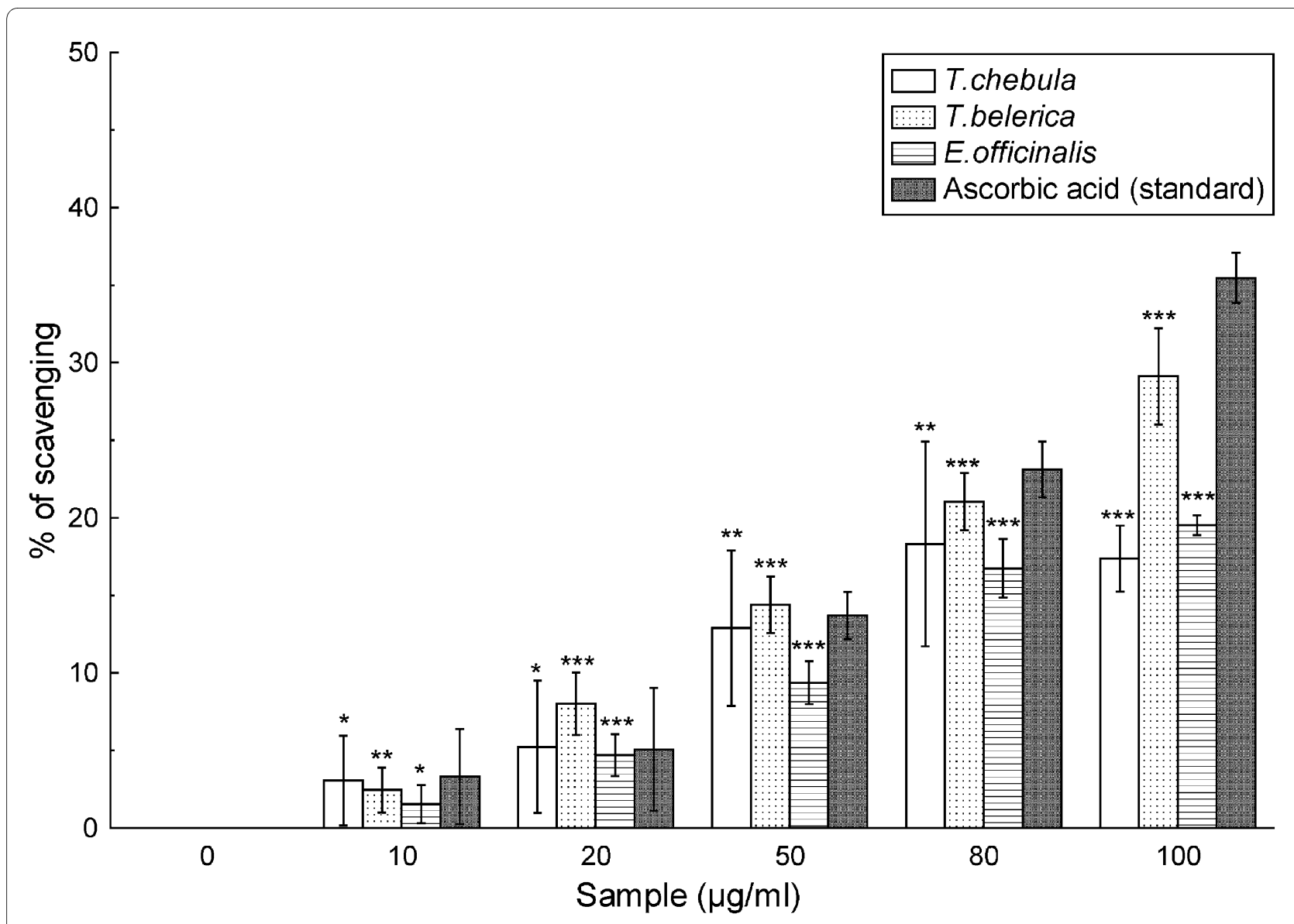

Figure $8 \mathrm{HOCl}$ scavenging assay. Hypochlorous acid scavenging activity of T. chebula, T. belerica and E. officinalis plant extracts and standard ascorbic acid. All data are expressed as mean \pm S.D. $(n=6) .{ }^{* *} p<0.01$ and ${ }^{* *} p<0.001 \mathrm{vs} 0 \mu \mathrm{g} / \mathrm{ml}$.

Hypochlorous acid is another harmful ROS. At the sites of inflammation, the oxidation of $\mathrm{Cl}^{-}$ions by the neutrophil enzyme myeloperoxidase results in the production of this ROS [38], which breaks down the heme prosthetic group and inactivates the antioxidant enzyme catalase. The obtained results (Figure 8) indicate that the standard ascorbic acid is a comparable scavenger to the fruit extracts (Table 2). So, it is anticipated that T. chebula, T. belerica and $E$. officinalis are efficient scavengers of $\mathrm{HOCl}$, with $T$. belerica being the most effective, just like in case of singlet oxygen.

The reducing capacity of a compound may serve as a significant indicator of its potential antioxidant activity. However, the activity of antioxidants has been attributed to various mechanisms such as prevention of chain initiation, decomposition of peroxides, reducing capacity and radical scavenging [39]. As shown in figure 9, the reducing power of the fruit extracts were compared with standard ascorbic acid and it was found that reducing capacity of the fruit extracts were although not better than standard, yet showed considerable activity with $E$. officinalis as the best among the three studied extracts.
The results indicate that the fruit extracts contain significant amount of flavonoids and phenolic content, in the order T. belerica $>$ E. officinalis $>T$. chebula and E. officinalis $>T$. belerica $>T$. chebula for the flavonoid and phenolic contents, respectively. Both of these compounds have good antioxidant potential and their effects on human nutrition and health are considerable. The mechanism of action of flavonoids is through scavenging or chelating process [40]. Phenolic contents are also very important plant constituents because of their scavenging ability due to their hydroxyl groups [41]. Moreover, ascorbic acid acting as a chain breaking antioxidant impairs with the formation of free radicals in the process of formation of intracellular substances throughout the body, including collagen, bone matrix and tooth dentine [42]. From the results, the trend for the ascorbic acid content was found to be $E$. officinalis $>T$. chebula $>T$. belerica .

We also observed that treating mice with total extracts of medicinal plants increased the activity of all antioxidant enzymes examined, including SOD, CAT, GST and GSH. These enzymes are modulated in various diseases by free radical attack, thus maintaining the balance 


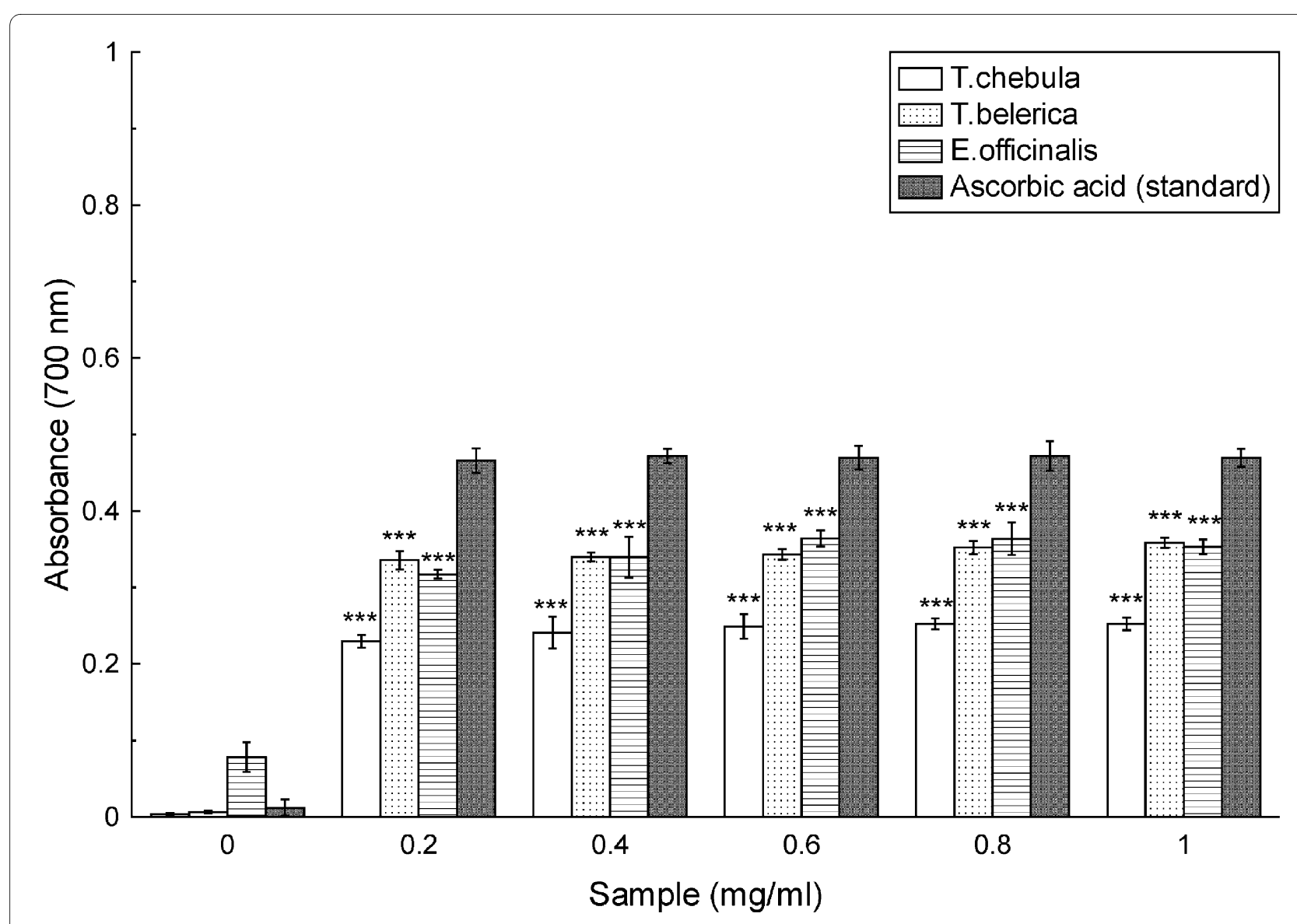

Figure 9 Reducing power assay. The reductive ability of T. chebula, T. belerica and E. officinalis extracts and standard Ascorbic acid. The absorbance $\left(A_{700}\right)$ was plotted against concentration of sample. Each value represents mean \pm S.D. $(n=6) .{ }^{* *} p<0.001 \mathrm{vs} 0 \mathrm{mg} / \mathrm{ml}$.
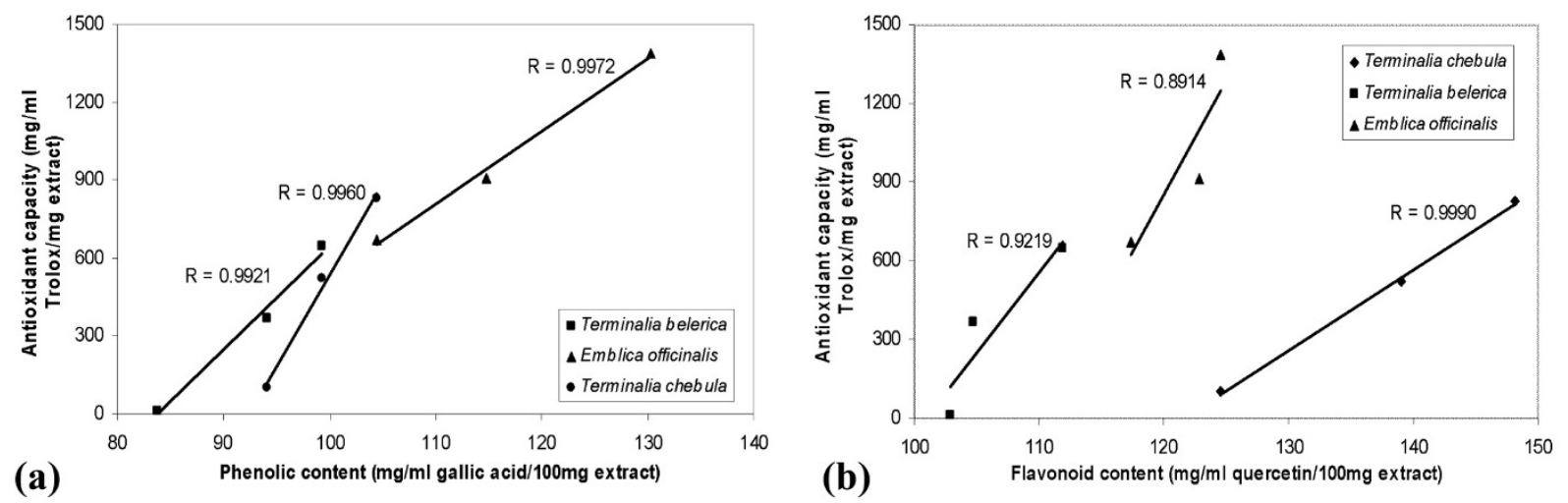

Figure 10 Correlation of antioxidant activity with phenolic and flavonoid contents. The relationship between (a) total phenolic content or (b) total flavonoid content in individual fruit and their antioxidant capacity. The correlation analyses were described as linear correlation coefficient (R). The differences were considered statistically significant if $p<0.05$. 
Table 3: Effect of the methanolic extract of the fruits of Terminalia chebula, Terminalia belerica and Emblica officinalis on the activities of antioxidant enzymes and reduced glutathione content in liver of normal mice

\begin{tabular}{|c|c|c|c|c|c|}
\hline & & \multicolumn{4}{|c|}{ Tested Parameters } \\
\hline \multicolumn{2}{|c|}{ Tested Samples } & SOD (U/mg protein) & CAT (U/mg protein) & GST (U/mg protein) & GSH ( $\mu \mathrm{g} / \mathrm{mg}$ protein) \\
\hline Control & Group I & $1.28 \pm 0.35$ & $0.29 \pm 0.16$ & $0.09 \pm 0.04$ & $2.8 \pm 0.7$ \\
\hline \multirow[t]{3}{*}{ Terminalia chebula } & Group II & $2.33 \pm 0.24^{* * *}$ & $0.51 \pm 0.22$ & $0.11 \pm 0.07$ & $3.35 \pm 0.5$ \\
\hline & Group III & $3.14 \pm 0.37^{* * * *}$ & $0.74 \pm 0.4$ & $0.26 \pm 0.05^{* *}$ & $3.52 \pm 0.5^{*}$ \\
\hline & Group IV & $3.75 \pm 0.27^{* * *}$ & $1.08 \pm 0.23^{*}$ & $0.37 \pm 0.04^{* * *}$ & $3.51 \pm 0.2$ \\
\hline \multirow[t]{3}{*}{ Terminalia belerica } & Group V & $2.61 \pm 0.22^{* * * *}$ & $0.43 \pm 0.06$ & $0.15 \pm 0.1$ & $3.42 \pm 0.3$ \\
\hline & Group VI & $3.62 \pm 0.24^{* * *}$ & $0.65 \pm 0.2$ & $0.67 \pm 0.15^{*}$ & $4 \pm 0.1$ \\
\hline & Group VII & $3.89 \pm 0.15^{* * *}$ & $0.66 \pm 0.1^{* *}$ & $0.71 \pm 0.3$ & $4.04 \pm 0.12$ \\
\hline \multirow[t]{3}{*}{ Emblica officinalis } & Group VIII & $2.31 \pm 0.18^{* *}$ & $0.33 \pm 0.2$ & $0.14 \pm 0.2$ & $3.04 \pm 0.07$ \\
\hline & Group IX & $4.01 \pm 0.17^{* * *}$ & $1.02 \pm 0.15^{* *}$ & $0.41 \pm 0.15^{*}$ & $3.85 \pm 0.2$ \\
\hline & Group X & $4.56 \pm 0.18^{* * *}$ & $1.06 \pm 0.1^{* *}$ & $0.64 \pm 0.1^{* *}$ & $4.13 \pm 0.1$ \\
\hline
\end{tabular}

Group I: Control group; Groups II, III and IV represent mice treated orally with the T. chebula extract in the doses of 10, 50 and $100 \mathrm{mg} / \mathrm{kg}$ body weight, respectively; Groups V, VI and VII contain mice treated orally with the T. belerica extract in a dose of 10,50 and $100 \mathrm{mg} / \mathrm{kg}$ body weight, respectively; Groups VIII, IX and X represent mice treated orally with the E. officinalis extract in a dose of 10,50 and $100 \mathrm{mg} / \mathrm{kg}$ body weight, respectively. Results are expressed as mean \pm SD for six mice in each group. ${ }^{*} p<0.05,{ }^{* *} p<0.01,{ }^{* * *} p<0.001$ compared to control.

between the rates of radical generation and scavenging. It is of particular interest to note that SOD catalyzes the breakdown of $\mathrm{O}_{2}$. to $\mathrm{O}_{2}$ and $\mathrm{H}_{2} \mathrm{O}_{2}$, and thus prevents the formation of $\mathrm{OH}$, and thereby, has been implicated as an essential defense against the potential oxygen toxicity. SOD catalyzes the breakdown of endogenous cytotoxic superoxide radicals to $\mathrm{H}_{2} \mathrm{O}_{2}$ which is further degraded by CAT. Thus, they play a crucial role in maintaining the physiological levels of $\mathrm{O}_{2}$ and $\mathrm{H}_{2} \mathrm{O}_{2}$. GSH, in conjunction with GST, has a basic role in cellular defense against deleterious free radicals and other oxidant species [43]. GST catalyzes the conjugation of thiol group of glutathione to electrophilic substrates, and thereby detoxifies endogenous compounds such as peroxidized lipids [44]. The present study supports the antioxidant potency of the fruit extract as evidenced by the increased level of these antioxidant systems in extract treated mice.

\section{Conclusions}

The results from various free radical scavenging systems revealed that all the fruit extracts were individually strong antioxidants, with some varying scavenging activities for different ROS at different magnitudes of potency. Furthermore, evaluation of in vivo antioxidant activity of these fruit extracts has also provided interesting results that might be beneficial for the pharmacological use of these plants in clinical trials. The wide use of these fruits in the Indian indigenous system of medicine as antiinflammatory and antihepatotoxic may be in part due to their antioxidant potency. Further, the isolation of the compounds responsible for the antioxidant activity has to be taken up which may result in modern drugs from these plants. Also the studies on antioxidant activity of the well known Ayurvedic formulation, Triphala, a mixture of these fruits, should be carried out and that is in progress.

Competing interests

The authors declare that they have no competing interests.

\section{Authors' contributions}

$\mathrm{BH}$ and $\mathrm{RS}$ both have performed the study such as extract preparation, antioxidant evaluation and animal experiments. They also have been involved in analysis of data and preparation of manuscript. SB has helped in the acquisition and statistical analysis of data. NM has been involved in study design, revising the manuscript and final approval of manuscript for submission. All authors have read and approved the final manuscript.

\section{Acknowledgements}

The authors would like to thank Mr. Ranjit Das for technical assistance in sample preparation, handling of lab wares and animals in experimental procedures.

Author Details

Division of Molecular Medicine, Bose Institute, P-1/12 CIT Scheme VIIM, Kolkata-700054, India

Received: 31 December 2009 Accepted: 13 May 2010

Published: 13 May 2010 


\section{References}

1. Braca A, Sortino C, Politi M, Morelli I, Mendez J: Antioxidant activity of flavonoids from Licania licaniaeflora. J Ethnopharmaco/ 2002, 79:379-381.

2. Maxwell SR: Prospects for the use of antioxidant therapies. Drugs 1995, 49:345-361.

3. Niki E, Shimaski H, Mino M: Antioxidantism-free radical and biological defense. Gakkai Syuppn Center, Tokyo 1994:3-16.

4. Finkel T, Holbrook NJ: Oxidants, oxidative stress and the biology of ageing. Nature 2000, 408:239-247.

5. Chopra RN, Nayar SL, Chopra IC: Glossary of Indian Medicinal Plants. CSIR, New Delhi, India 1956:106. 241, 242

6. Reddy VRC, Kumari SVR, Reddy BM, Azeem MA, Prabhakar MC, Appa Rao AVN: Cardiotonic activity of the fruit of Terminalia chebula. Fitoterapia 1990, LXI:517-525

7. Lee HS, Won NH, Kim KH, Lee H, Jun W, Lee KW: Antioxidant effects of aqueous extract of Terminalia chebula in vivo and in vitro. Biol Pharm Bull 2005, 28:1639-1644.

8. Aslokar L, Kakkar KK, Chakre OJ: Supplement to Glossary of Indian Medicinal Plants with Active Principles. Directorate CSIR, New Delhi, India 1992:291-293.

9. Rajarama Rao MR, Siddiqui HH: Pharmacological studies on Emblica officinalis Gaetn. Indian Exp Biol 1964, 2:29-31.

10. Halliwell B, Gutteridge JMC: Free radicals, ageing and disease. In Free Radicals in Biology and Medicine Clarendon: Oxford; 1985:279-315.

11. Roy AK, Dhir H, Talukdar G: Phyllanthus emblica fruit extract and ascorbic acid modify hepatotoxic and renotoxic effects of metals in mice. Int J Pharmacog 1991, 29:117-126.

12. Hazra B, Biswas $S$, Mandal N: Antioxidant and free radical scavenging activity of Spondias pinnata. BMC Complement Altern Med 2008, 8:63.

13. Mahakunakorn $\mathrm{P}$, Tohda M, Murakami Y, Matsumoto K, Watanabe $\mathrm{H}$ : Antioxidant and free radical-scavenging activity of Choto-san and its related constituents. Biol Pharm Bull 2004, 27:38-46.

14. Beckman JS, Chen $\mathrm{H}$, Ischiropulos H, Crow JP: Oxidative chemistry of peroxynitrite. Methods Enzymol 1994, 233:229-240.

15. Gu X, Chen C, Zhou T: Spectrophotometric method for the determination of ascorbic acid with iron (III)-1,10-phenanthroline after preconcentration on an organic solvent-soluble membrane filter. Fresenius J Anal Chem 1996, 355:94-95.

16. Lowry OH, Roesborough MJ, Farr AL, Randall RJ: Protein measurement with Folin-Phenol reagent. J Biol Chem 1951, 193:265-275.

17. Kakkar P, Das B, Viswanathan P: A modified spectrophotometric assay of superoxide dismutase. Indian J Biochem Biophys 1984, 21:130-132.

18. Bonaventura J, Schroeder WA, Fang S: Human erythrocyte catalase: an improved method of isolation and a revalution of reported properties. Arch Biochem Biophys 1972, 150:606-617.

19. Habig WH, Jakoby WB: Glutathione S-transferases. The first enzymatic step in mercapturic acid formation. J Biol Chem 1974, 249:7130-7139.

20. Ellman GL: Tissue sulfhydryl group. Arch Biochem Biophys 1959, 82:70-77.

21. Kuo PC, Damu AG, Cherng CY, Jeng JF, Teng CM, Lee EJ, Wu TS: Isolation of a natural antioxidant, dehydrozingerone from Zingiber officinale and synthesis of its analogues for recognition of effective antioxidant and antityrosinase agents. Arch Pharm Res 2005, 28:518-528.

22. Cheng HY, Lin TC, Yu KH, Yang CM, Lin CC: Antioxidant and Free Radical Scavenging Activities of Terminalia chebula. Biol Pharm Bull 2003, 26:1331-1335

23. Chattopadhyay RR, Bhattacharyya SK: Terminalia chebula: An update. Phcog Rev 2007, 1:151-156.

24. Sabu MC, Kuttan R: Anti-diabetic activity of some medicinal plantsrelation with their antioxidant property. Amala Res Bull 2000, 20:81-86.

25. Sabu MC, Kuttan R: Antidiabetic and antioxidant activity of Terminalia Belerica. Roxb. Indian J Exp Biol 2009, 47:270-275.

26. Bhattacharya A, Chatterjee A, Ghoshal S, Bhattacharya SK: Antioxidant activity of tannoid principles of Emblica officinalis (amla). Indian J Exp Biol 1999, 37:676-680.

27. Liu Xiaoli, Zhao Mouming, Wang Jinshui, Yang Bao, Jiang Yueming: Antioxidant activity of methanolic extract of emblica fruit (Phyllanthus emblica L.) from six regions in China. J Food Compos Anal 2008, 21:219-228.

28. Ng TB, Yeung HW: Scientific basis of the therapeutic effects of Ginseng. In Folk Medicine. The Art and the Science Edited by: Steiner RP. USA: American Chem Soc Publ; 1987:139-152.
29. Lissi EA, Modak B, Torres R, Escobar J, Urzua A: Total antioxidant potential of resinous exudates from Heliotropium species, and a comparison of the ABTS and DPPH methods. Free Rad Res 1999, 30:471-477.

30. Halliwell B: Reactive oxygen species in living systems: Source, biochemistry, and role in human disease. Am J Med 1991, 91:S14-S22.

31. Robak J, Gryglewski IR: Flavonoids are scavengers of superoxide anions. Biochem Pharmacol 1988, 37:837-841.

32. Miller MJ, Sadowska-Krowicka H, Chotinaruemol S, Kakkis JL, Clark DA: Amelioration of chronic ileitis by nitric oxide synthase inhibition. The J Pharmac and Experi Thera 1993, 264:11-16.

33. Huie RE, Padmaja S: The reaction of NO with superoxide. Free Radic Res Commun 1993, 18:195-199.

34. Balavoine GG, Geletti YV: Peroxynitrite scavenging by different antioxidants. Part 1: convenient study. Nitric oxide 1999, 3:40-54

35. Ischiropoulos $H$, al-Mehdi $A B$, Fisher $A B$ : Reactive species in ischemic rat lung injury: contribution of peroxynitrite. Am J Physiol 1995, 269:158-164. Elizabeth $\mathrm{K}$, Rao MNA: Oxygen radical scavenging activity of curcumin. Int J Pharmaceut 1990, 58: 237-240

36. Halliwell B: Reactive oxygen species in living systems: source, biochemistry, and role in human disease. Am J Med 1991, 91:14-22.

37. Kochevar El, Redmond WR: Photosensitized production of singlet oxygen. Methods Enzymol 2000, 319:20-28.

38. Aruoma Ol, Halliwell B, Hoey BM, Butler J: The antioxidant action of Nacetylcysteine: Its reaction with hydrogen peroxide, hydroxyl radical, superoxide, and hypochlorous acid. Free Rad Biol Med 1989, 6:593-597.

39. Duh PD, Tu YY, Yen GC: Antioxidant activity of water extract of Harng Jyur (Chrysenthemum morifolium Ramat). Lebnes wiss Technol 1999, 32:269-277

40. Yildirim A, Mavi A, Oktay M, Kara AA, Algur OF, Bilaloglu V: Comparison of antioxidant and antimicrobial activities of Tilia (Tilia argentea Desf Ex DC), Sage (Savia triloba L.), and Black Tea (Camellia sinensis) extracts. J Agri Food Chem 2000, 48:5030-5034.

41. Cook NC, Samman S: Flavonoids-chemistry, metabolism, cardioprotective effects, and dietary sources. Nutr Biochem 1996, 7:66-76.

42. Beyer RE: The role of ascorbate in antioxidant protection of biomembranes: interaction with vit-E and coenzyme. Q J Bioen Biomemb 1994, 24:349-358.

43. Arivazhagan S, Balasenthil S, Nagini S: Garlic and neem leaf extracts enhance hepatic glutathione and glutathione dependent enzymes during N-methyl-Nitrosoguanidine (MNNG)-induced gastric carcinogenesis. Phytother Res 2000, 14:291-293.

44. Leaver MJ, George SG: A piscine glutathione-S-transferase which efficiently conjugates the end products of lipid peroxidation. Mar Environ Res 1998, 46:33-35.

\section{Pre-publication history}

The pre-publication history for this paper can be accessed here: http://www.biomedcentral.com/1472-6882/10/20/prepub

\section{doi: $10.1186 / 1472-6882-10-20$}

Cite this article as: Hazra et al., Comparative study of the antioxidant and reactive oxygen species scavenging properties in the extracts of the fruits of Terminalia chebula, Terminalia belerica and Emblica officinalis BMC Complementary and Alternative Medicine 2010, 10:20 